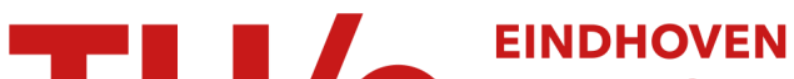 UNIVERSITY OF TECHNOLOGY
}

\section{Switching from infliximab innovator to biosimilar in patients with inflammatory bowel disease}

\section{Citation for published version (APA):}

Schmitz, E. M. H., Boekema, P. J., Straathof, J. W. A., van Renswouw, D. C., Brunsveld, L., Scharnhorst, V., van de Poll, M. E. C., Broeren, M. A. C., \& Derijks, L. J. J. (2018). Switching from infliximab innovator to biosimilar in patients with inflammatory bowel disease: A 12-month multicentre observational prospective cohort study. Alimentary Pharmacology and Therapeutics, 47(3), 356-363. https://doi.org/10.1111/apt.14453

DOI:

10.1111/apt.14453

Document status and date:

Published: 01/02/2018

\section{Document Version:}

Accepted manuscript including changes made at the peer-review stage

\section{Please check the document version of this publication:}

- A submitted manuscript is the version of the article upon submission and before peer-review. There can be important differences between the submitted version and the official published version of record. People interested in the research are advised to contact the author for the final version of the publication, or visit the $\mathrm{DOI}$ to the publisher's website.

- The final author version and the galley proof are versions of the publication after peer review.

- The final published version features the final layout of the paper including the volume, issue and page numbers.

Link to publication

\section{General rights}

Copyright and moral rights for the publications made accessible in the public portal are retained by the authors and/or other copyright owners and it is a condition of accessing publications that users recognise and abide by the legal requirements associated with these rights.

- Users may download and print one copy of any publication from the public portal for the purpose of private study or research.

- You may not further distribute the material or use it for any profit-making activity or commercial gain

- You may freely distribute the URL identifying the publication in the public portal.

If the publication is distributed under the terms of Article $25 \mathrm{fa}$ of the Dutch Copyright Act, indicated by the "Taverne" license above, please follow below link for the End User Agreement:

www.tue.nl/taverne

Take down policy

If you believe that this document breaches copyright please contact us at:

openaccess@tue.nl

providing details and we will investigate your claim. 


\title{
Switching from infliximab innovator to biosimilar in patients with inflammatory bowel disease: a 12-month multicentre observational prospective cohort study
}

\author{
E. M. H. Schmitz S $^{1,2,3,4}$ | P. J. Boekema ${ }^{5}$ | J. W. A. Straathof ${ }^{5}$ | D. C. van Renswouw ${ }^{6}$ | \\ L. Brunsveld ${ }^{2,4}$ | V. Scharnhorst ${ }^{2,3,4}$ | M. E. C. van de Poll ${ }^{7}$ M. A. C. Broeren ${ }^{1,2}$ | \\ L. J. J. Derijks ${ }^{7}$
}

${ }^{1}$ Clinical Laboratory, Máxima Medical Center, Veldhoven, The Netherlands

${ }^{2}$ Expert Center Clinical Chemistry,

Eindhoven, The Netherlands

${ }^{3}$ Clinical Laboratory, Catharina Hospital, Eindhoven, The Netherlands

${ }^{4}$ Laboratory of Chemical Biology and Institute for Complex Molecular Systems,

Eindhoven University of Technology,

Eindhoven, The Netherlands

${ }^{5}$ Department of Gastroenterology, Máxima Medical Center, Eindhoven and Veldhoven, The Netherlands

${ }^{6}$ Department of Clinical Pharmacy, Elkerliek Hospital, Helmond, The Netherlands

${ }^{7}$ Department of Clinical Pharmacy and Pharmacology, Máxima Medical Center, Veldhoven, The Netherlands

\section{Correspondence}

Dr. L Derijks, Clinical Pharmacy, Máxima

Medical Center, Veldhoven, The

Netherlands.

Email: L.Derijks@mmc.nl

\section{Summary}

Background: Infliximab biosimilars have become available for treatment of inflammatory bowel disease (IBD). However, data showing long-term safety and effectiveness of biosimilars in IBD patients are limited.

Aim: To study prospectively the switch from infliximab innovator to biosimilar in an IBD cohort with 12 months follow-up to evaluate safety and effectiveness.

Methods: Adult IBD patients from two hospitals treated with infliximab innovator (Remicade; Janssen Biotech, Horsham, Pennsylvania, USA) were switched to infliximab biosimilar (Inflectra; Hospira, Lake Forest, Illinois, USA) as part of routine care, but in a controlled setting. Blood samples were taken just before the first, second, fourth and seventh infusion of biosimilar. Infliximab trough levels, antibodies-toinfliximab (ATI), CRP and ESR were measured and disease activity scores were calculated.

Results: Our cohort consisted of 133 IBD patients (64\% CD, 36\% UC). Before switching we found widely varying infliximab levels (median $3.5 \mu \mathrm{g} / \mathrm{mL}$ ). ATI were detected in eight patients (6\%). Most patients were in remission or had mild disease (CD: 82\% UC: 90\%). After switching to biosimilar, 35 patients (26\%) discontinued therapy within 12 months, mostly due to subjective higher disease activity (9\%) and adverse events (AE, 9.8\%). AE included general malaise/fatigue ( $n=7)$, arthralgia $(n=2)$, skin problems $(n=2)$ and infusion reactions $(n=2)$. No differences in IFX levels, CRP, and disease activity scores were found between the four time points $(P \geq .0917)$.

Conclusions: We found no differences in drug levels and disease activity between infliximab innovator and biosimilar in our IBD cohort, indicating that biosimilars are safe and effective. The high proportions of discontinuers were mostly due to elective withdrawal or subjective disease worsening. 


\section{1 | INTRODUCTION}

Inflammatory bowel disease (IBD) is characterised by chronic inflammation of the gastrointestinal tract, with two main subtypes: Crohn's disease (CD) and ulcerative colitis (UC). IBD patients often experience disease flares and significantly decreased quality of life. ${ }^{1,2}$ The introduction of biological therapies two decades ago revolutionised the treatment of moderate to severe IBD. ${ }^{3}$ Two years ago, a new landmark in IBD treatment was set with the introduction of the first biosimilars. Biosimilars are highly similar to the innovator biologics, but much cheaper.

In 2015, the patent of infliximab (IFX), the first anti-tumour necrosis factor (TNF $\alpha$ ) biological, expired and two infliximab biosimilars entered the market: Inflectra and Remsima (both CTP13). Registration studies in patients with rheumatoid arthritis (RA) and ankylosing spondylitis (AS) showed that IFX innovator (Remicade) and IFX biosimilar (CTP-13) had comparable pharmacokinetics, efficacy, safety and immunogenicity ${ }^{4-7}$ and that it was safe to switch from IFX innovator to biosimilar. ${ }^{8,9}$ Treatment approval was extrapolated to include all indications approved for treatment with the innovator, which also includes IBD. However, data on the use of biosimilars in IBD patients are still scarce and many healthcare professionals and patients are yet to be convinced. Several concerns have been raised ${ }^{10}$ : the different dosing $(5 \mathrm{mg} / \mathrm{kg}$ in IBD and $3 \mathrm{mg} / \mathrm{kg}$ in rheumatic disorders), the use of different concomitant immunosuppressive medication (which is more common and different in rheumatic diseases than in IBD), and the potentially different mechanism of anti-TNF $\alpha$ biologics in rheumatic conditions and IBD. ${ }^{11-13}$

There are currently only a few studies available that show data of IBD patients who were treated with a biosimilar. Moreover, these studies often have a limited amount of patients, limited information about drug levels and anti-drug-antibodies, and often only show short-term data. Therefore, we prospectively studied the switch from infliximab innovator to biosimilar in a large cohort of IBD patients with a 1 year follow-up to evaluate long-term safety and effectiveness.

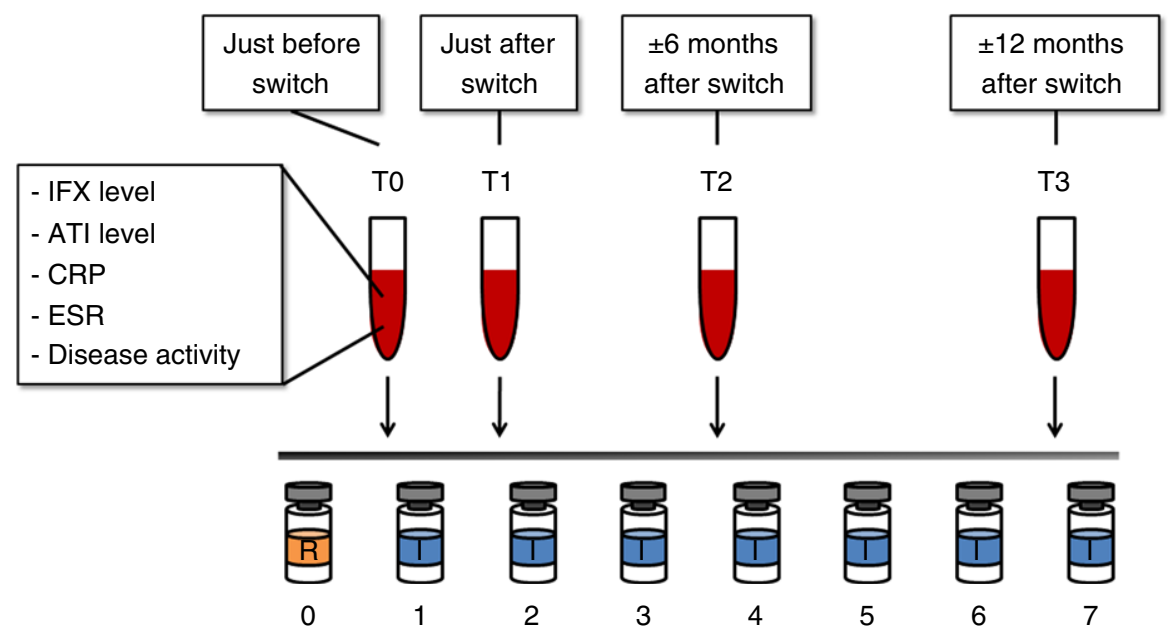

\section{2 | MATERIALS AND METHODS}

\section{1 | Patients and study design}

All adult IBD patients treated with infliximab in Máxima Medical Center (Veldhoven, the Netherlands) and Elkerliek hospital (Helmond, the Netherlands) were included. Patients were switched from innovator Remicade to biosimilar Inflectra as part of routine care. In both hospitals the same switching protocol was used. All patients received a letter from their gastroenterologists which described that the infliximab treatment changed from Remicade to Inflectra, a different brand, and that studies showed that these drugs are highly similar. Essentially, patients were switched to biosimilar unless there were severe doubts. In these rare cases, the physician gave the patient a thorough explanation of the biosimilar concept, which could persuade them to switch. All patients agreed to this change in treatment.

The switch was performed in a controlled setting (Figure 1): blood samples were taken just before the first infusion (TO), and after the second (T1), fourth (T2) and seventh (T3) infusion of Inflectra. These time points reflect the patient's status just before and after the switch and after approximately six and twelve months. The following parameters were measured in blood: IFX trough levels, antibodies to infliximab (ATI, only if IFX $<0.5 \mu \mathrm{g} / \mathrm{mL}$ ), C-reactive protein (CRP) and erythrocyte sedimentation rate (ESR). Concomitantly, disease activity scores were determined.

Since the switch was done as part of routine care, actions could be taken as a consequence of the measured IFX levels if necessary. For example, patients with high ATI levels were switched to a different therapy, and patients who had undetectable IFX levels and deep sustained remission (stop criterion defined by the Dutch gastroenterologist's society ${ }^{14}$ ) discontinued IFX therapy.

\section{2 | Infliximab and ATI measurements}

IFX levels were measured in-house using an Infliximab ELISA kit (apDia, Turnhout, Belgium) on an automated ELISA processing

FIGURE 1 Study design of the switching protocol from infliximab innovator (Remicade, R) to infliximab biosimilar (Inflectra, I). Blood samples were taken at four different time points, from which different parameters were determined. IFX = infliximab, $\mathrm{ATI}=$ antibodies to infliximab, CRP = C-reactive protein, ESR = erythrocyte sedimentation rate 
system. ${ }^{15} \mathrm{ATI}$ were only measured when the IFX level was $<0.5 \mu \mathrm{g} /$ $\mathrm{mL}$. During the first part of the switch study, samples were sent to Sanquin Diagnostics (Amsterdam, the Netherlands), ${ }^{16}$ while during the second part of the study ATI levels were measured in-house using the anti-Infliximab ELISA kit (apDia, Turnhout, Belgium). Validation studies showed that there was good correlation between these assays. $^{17}$

\section{3 $\quad$ Disease activity scores}

Validated disease activity scores were calculated to determine the disease activity. For CD patients the Crohn's disease activity index (CDAI) was used. ${ }^{18}$ The Truelove-Witts disease activity index (TWDAI) was used for UC patients. ${ }^{19}$

\subsection{Statistical analysis}

First, data were analysed with the Shapiro-Wilk test to determine if it was normally distributed. This was not the case, so non-parametric statistical analysis was used. Comparison of infliximab, CRP and ESR levels between the four time points was done using Friedman analysis. If Friedman analysis returned a statistically significant difference, the Wilcoxon signed rank test was subsequently used to analyse differences between all time points in pairs. For comparison of the disease activity scores, the score at T0 was compared to the average score after switching to biosimilar therapy. This was done using the Wilcoxon Mann-Whitney test. $P<.05$ were considered statistically significant.

\section{3 | RESULTS}

\section{1 | Patients}

Our cohort consisted of 133 IBD patients, of which approximately two-third had CD and one-third had UC. They had been receiving

TABLE 1 Demographics of our IBD cohort

\begin{tabular}{lcc|}
$\begin{array}{l}\text { Characteristics } \\
\text { Sex }\end{array}$ & Crohn's disease & Ulcerative colitis \\
\hline Female & $52(60 \%)$ & $22(46 \%)$ \\
\hline Male & $34(40 \%)$ & $25(52 \%)$ \\
\hline Age $(y)$ & $41(29-51)$ & $49(42-60)$ \\
\hline Infliximab dose (mg) & $400(300-400)$ & $400(300-400)$ \\
\hline Interval (wk) & $8(6-8)$ & $8(8-8)$ \\
\hline Duration infliximab therapy (mo) & $53(33-74)$ & $50(35-65)$ \\
\hline Immunosuppressive comedication & & \\
\hline \multicolumn{1}{l}{ none } & $46(54 \%)$ & $22(47 \%)$ \\
\hline thiopurines & $33(39 \%)$ & $22(47 \%)$ \\
\hline corticosteroids & $4(5 \%)$ & $2(4 \%)$ \\
\hline thiopurine + corticosteroid & $1(1 \%)$ & $1(2 \%)$ \\
\hline methotrexate & $1(1 \%)$ & $0(0 \%)$ \\
\hline
\end{tabular}

Data are represented as [n (\%)] or [median (IQR)].

$\mathrm{IQR}=$ interquartile range. infliximab innovator therapy for a median of 52 months before switching to the biosimilar. Half of the patients received concomitant immunosuppressive therapy (48\%), of which thiopurines were most common. More details can be found in Table 1.

\subsection{Status on Remicade therapy}

Before switching to biosimilar therapy, the patients' status on innovator therapy was determined (TO). We found widely varying IFX levels, ranging from undetectably low to very high (Figure 2). The median IFX level of the whole cohort was $3.5 \mu \mathrm{g} / \mathrm{mL}(3.7 \mu \mathrm{g} / \mathrm{mL}$ for $\mathrm{CD}$ patients and $2.9 \mu \mathrm{g} / \mathrm{mL}$ for UC patients). The proposed therapeutic range for IBD patients is $3-7 \mu \mathrm{g} / \mathrm{mL}^{20-23}$ If we apply this range to our cohort, $40 \%$ of all CD patients had levels within the therapeutic range, whereas $27 \%$ of the UC patients reached adequate levels. In both populations, $21 \%$ had high IFX levels $(>7 \mu \mathrm{g} /$ $\mathrm{mL})$. Low IFX levels $(<3 \mu \mathrm{g} / \mathrm{mL})$ were found in $39 \%$ of the $\mathrm{CD}$ patients, 9\% had even undetectably low levels $(<0.5 \mu \mathrm{g} / \mathrm{mL})$. For UC patients, we found that $52 \%$ had low IFX levels, $21 \%$ had undetectably low levels.

Antibodies-to-infliximab (ATI) were measured in eighteen patients. Ten patients (four CD, six UC patients) had no detectable ATI, while eight patients (four CD, four UC patients) had detectable ATI. Two of these eight patients (one CD, one UC patient) had very high ATI levels (>880 au). Infliximab therapy was discontinued in patients with very high ATI. Therapy was continued for the patients with low ATI levels, since it was shown that ATI can be transient and thus not necessarily have negative influence on the therapy. ${ }^{24,25}$

CRP levels were elevated for 25 patients (19\%). Disease activity scores at T0 were available for 65 CD patients (76\%) and 29 UC patients (60\%). The great majority of patients was in remission or had mild disease ( $82 \%$ of CD patients and $90 \%$ of UC patients). The rest, a minority, had moderate disease (see Figure $3, \mathrm{TO}$ ). No patients had severe disease activity. No statistically significant correlation could be found between drug levels and disease activity scores.

\subsection{Switching to IFX biosimilar: comparison of different time points}

To determine effectiveness and safety of infliximab biosimilar, we firstly analysed if there were differences in IFX levels, CRP and disease activity scores between IFX innovator and biosimilar. Dose and frequency were never changed between T0 and T1. Also during the rest of the study, patients stayed on the same dose and frequency during the study, apart from a few exceptions. Median IFX levels varied from 3.5 to $4.2 \mu \mathrm{g} / \mathrm{mL}$, median CRP levels varied from 1.4 to $2.0 \mathrm{mg} / \mathrm{L}$. Both were not statistically significantly different between the four time points (IFX: $P=.4106$ and CRP: $P=.0981$, Figure 4). Disease activity scores before and after switching were also not statistically significantly different (CDAl: $P=.5657$ and TWDAl: $P=.7609$ ). This is supported by Figure 3 , which shows that the amount of patients that had no/low disease activity and patients 
that had moderate disease activity were comparable between the four time points.

After switching to biosimilar therapy, patients were monitored at three time points during the first year. The therapy was discontinued by 35 patients $(26 \%)$ in total, $23 \mathrm{CD}$ patients (26\%) and $13 \mathrm{UC}$ patients (27\%). Approximately half of those patients used concomitant immunosuppressive medication, which is similar to the whole population. Most patients discontinued due to higher disease activity or adverse events (Table 2). The majority discontinued biosimilar therapy due to adverse events (9.8\% of the cohort). The most common adverse event was general malaise and/or fatigue $(n=7)$. Other adverse events were arthralgia $(n=2)$, skin problems $(n=2)$, infusion reaction to the first biosimilar infusion $(n=2)$, anaphylactic response to biosimilar infusion $(n=1)$ and suspected delayed allergic reaction $(n=1)$. Furthermore, 12 patients ( $9 \%$ of the cohort) experienced higher disease activity. In the majority of cases, complaints about higher disease activity were not objectified with higher disease activity scores or increased CRP $(n=8)$. Increased disease activity was only objectified in two patients. In two cases, patients also had high disease activity on infliximab innovator therapy. Last, five patients (3.8\% of the cohort) discontinued biosimilar therapy because they were in remission, one patient temporarily stopped IFX therapy because she was expecting labour and two patients accidently received innovator instead of biosimilar.

Different follow-up strategies were applied for the patients who stopped biosimilar therapy. The majority of discontinuers (63\%) were switched back to infliximab innovator therapy. Four patients (11\% of discontinuers) switched to vedolizumab (Entyvio; Takeda Pharmaceuticals, Osaka, Japan), an anti- $\alpha_{4} \beta_{7}$ integrin antibody. Nine patients ( $26 \%$ of discontinuers) discontinued biologics therapy completely because they were in remission $(n=5)$, because they already had complaints while receiving infliximab innovator $(n=2)$, because they had high ATI levels $(n=1)$ or because they were expecting labour $(n=1)$.

At TO, eight patients had detectable ATI. After switching, only two of these patients stayed on biosimilar therapy during the first twelve months ( $2 \%$ of continuers); one continued to have detectable ATI, while ATI disappeared for the other. The other six patients with detectable ATI at TO discontinued biosimilar therapy during the first 12 months after switching to biosimilar (17\% of discontinuers). Three of these patients discontinued biosimilar because they were in remission, one was switched to vedolizumab and two were switched back to infliximab innovator therapy. The relative risk (RR) of discontinuing biosimilar therapy for patients with detectable ATI before switching was 3.2 (95\% Cl 1.9-5.4) compared to patients with no ATI before switching. This indicates that patients with autoimmune response to IFX have a statistically significantly higher risk on therapy discontinuation.

Three patients developed ATI after switching to biosimilar therapy. One of these patients had a low ATI level after the first infusion of biosimilar, but they disappeared after the second infusion. The second patient experienced an allergic reaction to the first biosimilar
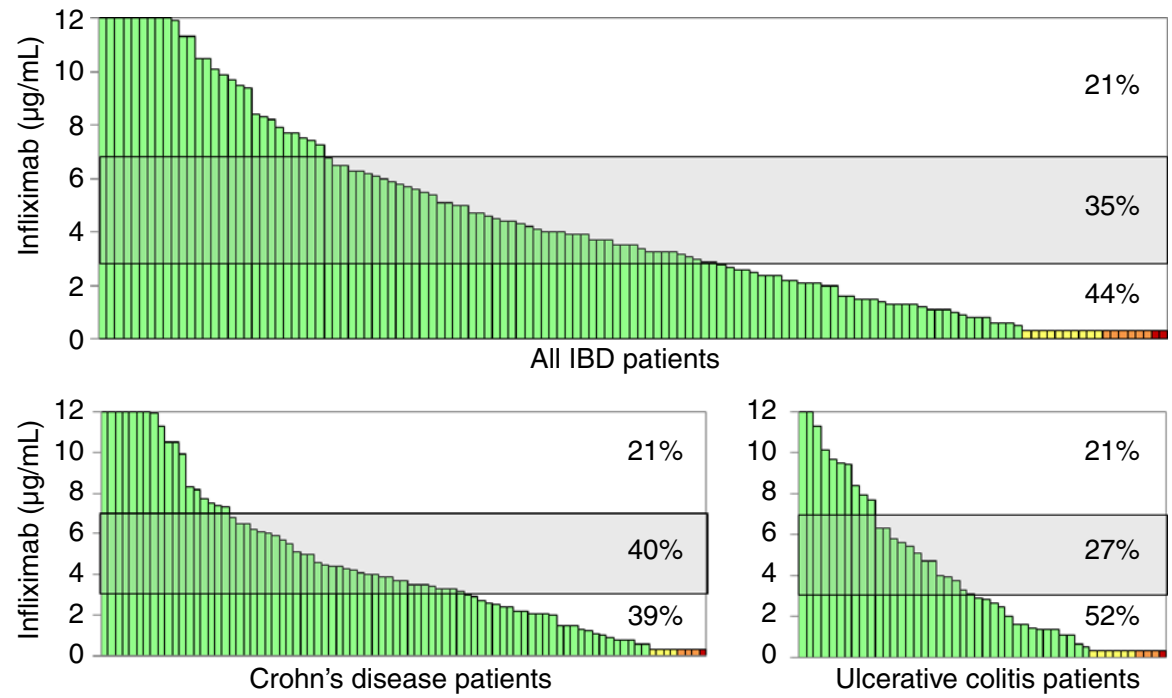

口 IFX $>0.5 \mu \mathrm{g} / \mathrm{mL}$ 口 IFX $<0.5 \mu \mathrm{g} / \mathrm{mL}$, no ATI 口IFX $<0.5 \mu \mathrm{g} / \mathrm{mL}$, low ATI घ IFX $<0.5 \mu \mathrm{g} / \mathrm{mL}$, high ATI
FIGURE 2 Trough levels of infliximab (IFX) and antibodies-to-infliximab (ATI) of our IBD cohort before switching to IFX biosimilar (TO). Data are split into Crohn's disease (bottom left) and ulcerative colitis (bottom right). The proposed therapeutic range of 3-7 $\mu \mathrm{g} / \mathrm{mL}$ is indicated with the light grey rectangle. The percentage of patients with IFX levels within, below or above the therapeutic range are indicated. ATI levels are indicated with yellow, orange and red bars
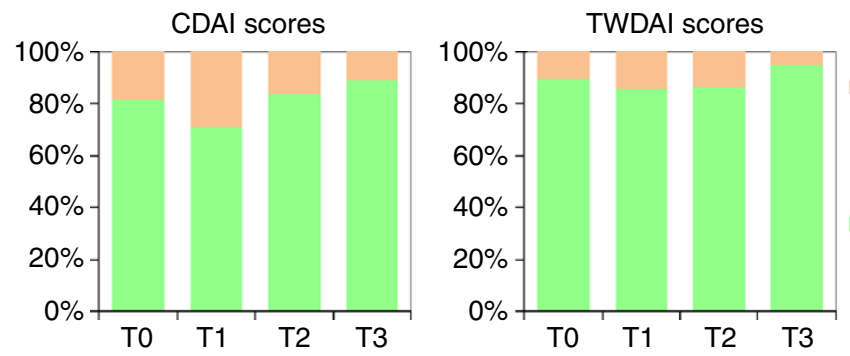

Moderate disease

CDAI 150-400

TWDAI 11-14

Remission or mild disease CDAI $<150$ TWDAI 6-10
FIGURE 3 Disease activity scores for Crohn's disease patients (left) and ulcerative colitis patients (right) before switching to infliximab biosimilar (TO) and at the different time points after switching to biosimilar (T1-T3) 
infusion, after which we found a high ATI level. The third patient had continuously undetectable IFX levels, but only detectable ATI during the last measurement, indicating that the immune response against IFX was recently triggered.

\section{DISCUSSION}

The use of infliximab biosimilars could greatly reduce treatment costs of IBD patients. Infliximab biosimilars are highly similar to infliximab innovator but less expensive (estimated up to $40 \%$ ) due to competition in the market. ${ }^{24}$ However, data demonstrating its clinical safety and effectiveness in real-life IBD patients are still limited and further studies are needed to support the use of infliximab biosimilar in IBD patients (reviewed $\mathrm{in}^{26,27}$ ). Therefore, we switched our IBD cohorts receiving IFX innovator to biosimilar as part of routine care, but in a controlled setting, using therapeutic drug monitoring (TDM).
In our study, we first determined the patients' status at IFX innovator therapy. Despite (empiric) therapy optimisation by the gastroenterologists, a broad range of IFX levels was found. Approximately one-third of the patients had concentrations within the proposed therapeutic range of $3-7 \mu \mathrm{g} / \mathrm{mL} .{ }^{20-23}$ Most patients had IFX levels below this therapeutic range, for UC patients this was even half the population (52\%). However, we also found that the majority of our patients was in remission or had low disease activity. No correlation between IFX levels and disease activity was found. A possible explanation for this is that our cohort did not include patients with high disease activity. Also, TDM was already applied on a part of this cohort 2 years ago, ${ }^{28}$ which 'dilutes' the concentration-activity relationship.

Antibodies to infliximab (ATI) were detected in eight patients ( $6 \%$ of the total cohort). This number is somewhat lower than usually reported in literature for IBD patients. ${ }^{24,29,30}$ This could be due to our gastroenterologists' policy to sometimes perform TDM as part of routine care, especially when a patient has higher disease activity.
Infliximab $(\mu \mathrm{g} / \mathrm{mL})$

T2

T2
$\square$

reactive protein (CRP) concentrations for all patients before switching to biosimilar (TO) and after switching to IFX biosimilar therapy (T1-T3). The box and whisker plots show the median IFX values, interquartile range and total range
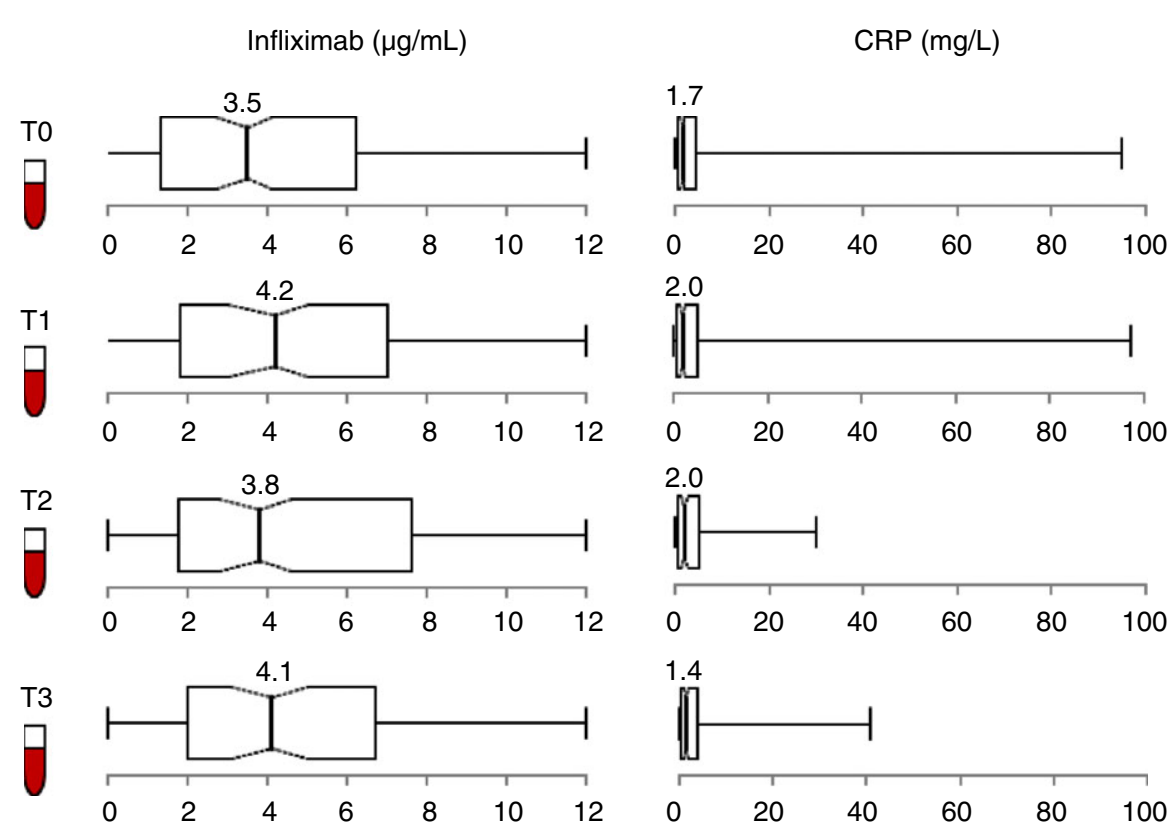

TABLE 2 Characteristics of the patient group who discontinued biosimilar therapy. Percentages are calculated with respect to the whole population $(\mathrm{n}=133)$

\begin{tabular}{|c|c|c|c|c|}
\hline Reason drop-out & n (\%) & $\begin{array}{l}\text { Probably } \\
\text { switch-related }\end{array}$ & $\begin{array}{l}\text { Possibly } \\
\text { switch-related }\end{array}$ & $\begin{array}{l}\text { Not } \\
\text { switch-related }\end{array}$ \\
\hline Higher disease activity & $12(9.0 \%)$ & 2 & 8 & 2 \\
\hline Adverse events & $13(9.8 \%)$ & - & - & - \\
\hline -infusion reaction & - & 1 & - & - \\
\hline -delayed allergic response & - & 1 & - & - \\
\hline -general malaise/tired & - & - & 7 & - \\
\hline -arthralgia & - & - & 2 & - \\
\hline -skin problems & - & - & 2 & - \\
\hline Antibodies to infliximab & $2(1.5 \%)$ & - & - & 2 \\
\hline In remission & $5(3.8 \%)$ & - & - & 5 \\
\hline Other & $3(2.3 \%)$ & - & - & 3 \\
\hline
\end{tabular}


This could make this population slightly biased towards lower disease activity or lower number of patients with detectable ATI. However, some studies do not report IFX and/or ATI levels at all,,30-32 which makes comparison difficult.

Six of the eight patients who had detectable ATI at TO discontinued biosimilar therapy within the first 12 months. We found that patients with detectable ATI before switching had a relative risk of 3.2 for discontinuation of biosimilar therapy compared to patients with no ATI. This indicates that patients with autoimmune response to IFX have a statistically significantly higher risk on therapy failure. It was shown that antibodies to IFX innovator are highly similar to antibodies to the biosimilar, ${ }^{33,34}$ so these patients would probably also have experienced therapy failure if they would have stayed on innovator therapy.

No statistically significant differences in drug levels, disease activity scores or inflammation marker CRP were found between IFX innovator and biosimilar. This indicates that safety and effectiveness of the biosimilar are good and that switching from IFX innovator to biosimilar is feasible. However, $26 \%$ of patients in our cohort discontinued biosimilar therapy, which was mostly due to adverse events (9.8\% of the cohort) or higher disease activity (9.0\% of the cohort). Higher disease activity was objectified in only two patients (1.5\% of the whole cohort). The high amount of patients discontinuing biosimilar therapy with non-objectified lack of effectiveness or general malaise could be explained by the low threshold that was applied to switch back to innovator therapy for the first biosimilar switch in our hospital. Patients were easily put back on innovator treatment if they had complaints that could possibly be switchrelated due to the lack of experience with biosimilars in clinical practice. Objective measurement of disease activity using questionnaires is not yet part of routine care in our hospitals and was thus unfortunately not always applied before making the decision to discontinue biosimilar therapy. Besides, the novelty of biosimilars could induce the nocebo effect in patients (disease worsening due to negative expectations), so disease worsening is not necessarily due to a lack of effectiveness. This is a drawback of nondouble-blinded studies and we believe this is an important cause of finding such high numbers of biosimilar discontinuation.

Another important reason for discontinuation is the occurrence of adverse events ( $9 \%$ of the population). Increased fatigue, skin problems and arthralgia were most commonly mentioned by patients. These could possibly be switch-related, but also be induced by the nocebo effect. There was one patient ( $0.8 \%$ of the cohort) who experienced an infusion reaction, which is similar to other studies. Infusion reactions reported in literature were $6.9 \%$ in the PROSIT-BIO study, ${ }^{31} 2 \%$ in the NOR-SWITCH ${ }^{29}$ and none in the study by Arguëlles-Arias et al. and Smits et al. ${ }^{32,35}$

Five patients (3.8\%) discontinued biosimilar therapy because they experienced deep sustained remission and met the STOP criteria. ${ }^{14}$ Several studies showed that most patients who discontinue antiTNF $\alpha$ therapy while in deep sustained remission continue to be in remission, ${ }^{26,36,37}$ especially when patients have undetectable IFX levels before discontinuation. ${ }^{37}$ Three of our five patients who discontinued IFX maintained remission, while the other two experienced mild disease worsening. None of the patients restarted IFX therapy; four are taking different medication and one is medicationfree.

The number of dropouts in our study is higher than usually reported in literature. In the NOR-SWITCH study, the only randomised double-blind trial available, $1.2 \%$ of patients discontinued biosimilar therapy due to lack of effectiveness and $3.0 \%$ due to adverse events within the first 12 months. ${ }^{29}$ However, the doubleblind setup of the NOR-SWITCH study excludes possible bias caused by the nocebo effect. In our study both patient and gastroenterologist knew about the switch from innovator Remicade to biosimilar Inflectra. This could explain the higher drop-out rate in our study. Moreover, all patients included in the NOR-SWITCH study were in remission at the start of the study, while only $84 \%$ of our patients had no/mild disease activity. Several other switch studies report similar numbers of patients who discontinue biosimilar treatment to the NOR-SWITCH study, ${ }^{31,32,35,38}$ though it has to be noted that the duration of all these studies was shorter than twelve months. However, there are also several switch studies which reported similar numbers of patients that discontinued biosimilar therapy as our study. ${ }^{39,40}$ These switch studies were performed in real-life cohorts and reported that a significant amount of patients discontinued due to elective withdrawal or subjective disease worsening.

In conclusion, we found no differences in drug levels and disease activity between infliximab biosimilar and innovator in our IBD cohort, indicating that the biosimilar is safe and effective. A relatively high proportion of patients discontinued biosimilar therapy within the first year, but this is probably due to the nonblinded setup of our study and the fact that a real-life cohort was monitored rather than a well-defined and pre-selected population, which induces the nocebo effect. Switching to biosimilar and performing TDM as part of routine care can optimise IFX therapy efficiently and make it more cost-effective.

\section{ACKNOWLEDGEMENTS}

Declaration of personal and funding interests: None.

\section{AUTHORSHIP}

Guarantor of the article: Derijks Luc JJ.

Author contributions: Schmitz, Ellen Maria Hubertina, performed the research, collected and analysed the data, wrote the paper; Boekema, Paul, designed the research study, commented on the paper; Straathof, Jan-Willem, designed the research study, commented on the paper; van Renswouw, Dein, collected the data, commented on the paper; Brunsveld, Luc, designed the research study, commented on the paper; Scharnhorst, Volkher, designed the research study, commented on the paper; van de Poll, Matthijs, collected the data, commented on the paper; Broeren, Maarten, designed the research study, wrote the paper; Derijks, Luc JJ, collected the data, designed 
the research study, wrote the paper. All authors approved the final version of the manuscript.

\section{ORCID}

\section{J. J. Derijks (iD http://orcid.org/0000-0002-6038-9295}

\section{REFERENCES}

1. Lönnfors S, Vermeire S, Greco M, Hommes D, Bell C, Avedano L. IBD and health-related quality of life - discovering the true impact. $J$ Crohns Colitis. 2014;8:1281-1286.

2. Becker HM, Grigat D, Ghosh S, et al. Living with inflammatory bowel disease: a crohn's and colitis Canada survey. Can J Gastroenterol Hepatol. 2015;29:77-84.

3. Côté-Daigneault J, Bouin M, Lahaie R, Colombel J-F, Poitras P. Biologics in inflammatory bowel disease: what are the data? United Eur Gastroenterol J. 2015;3:419-428.

4. Park W, Hrycaj P, Jeka S, et al. A randomised, double-blind, multicentre, parallel-group, prospective study comparing the pharmacokinetics, safety, and efficacy of CT-P13 and innovator infliximab in patients with ankylosing spondylitis: the PLANETAS study. Ann Rheum Dis. 2013;72:1605-1612.

5. Yoo DH, Hrycaj P, Miranda P, et al. A randomised, double-blind, parallel-group study to demonstrate equivalence in efficacy and safety of CT-P13 compared with innovator infliximab when coadministered with methotrexate in patients with active rheumatoid arthritis: the PLANETRA study. Ann Rheum Dis. 2013;72:1613-1620.

6. Park W, Lee SJ, Yun J, Yoo DH. Comparison of the pharmacokinetics and safety of three formulations of infliximab (CT-P13, EU-approved reference infliximab and the US-licensed reference infliximab) in healthy subjects: a randomized, double-blind, three-arm, parallelgroup, single-dose, Phase I study. Expert Rev Clin Immunol. 2015;11: S25-S31.

7. Yoo DH, Racewicz A, Brzezicki J, et al. A phase III randomized study to evaluate the efficacy and safety of CT-P13 compared with reference infliximab in patients with active rheumatoid arthritis: 54-week results from the PLANETRA study. Arthritis Res Ther. 2015;18:82.

8. Park W, Yoo DH, Jaworski J, et al. Comparable long-term efficacy, as assessed by patient-reported outcomes, safety and pharmacokinetics, of CT-P13 and reference infliximab in patients with ankylosing spondylitis: 54-week results from the randomized, parallel-group PLANETAS study. Arthritis Res Ther. 2016;18:25.

9. Yoo DH, Prodanovic N, Jaworski J, et al. Efficacy and safety of CTP13 (biosimilar infliximab) in patients with rheumatoid arthritis: comparison between switching from reference infliximab to CT-P13 and continuing CT-P13 in the PLANETRA extension study. Ann Rheum Dis. 2016;76:355-363.

10. Danese S, Gomollon F, Governing Board and Operational Board of ECCO. ECCO position statement: the use of biosimilar medicines in the treatment of inflammatory bowel disease (IBD). J Crohns Colitis. 2013;7:586-589.

11. Van den Brande JMH, Koehler TC, Zelinkova Z, et al. Prediction of antitumour necrosis factor clinical efficacy by real-time visualisation of apoptosis in patients with Crohn's disease. Gut. 2007;56:509-517.

12. Tilg $\mathrm{H}$, Moschen A, Kaser A. Mode of function of biological anti-TNF agents in the treatment of inflammatory bowel diseases. Expert Opin Biol Ther. 2007;7:1051-1059.

13. Danese $\mathrm{S}$. Mechanisms of action of infliximab in inflammatory bowel disease: an anti-inflammatory multitasker. Dig Liver Dis. 2008;40: S225-S228.
14. Nederlandse vereniging van Maag Darm Leverartsen. START-STOP document biologicals. [cited 2014 Oct 21]. Available from: http:// www.mdl.nl/richtlijnen2? noCache $=345 ; 1413899557$

15. Schmitz EMH, de van Kerkhof D, Hamann D, et al. Therapeutic drug monitoring of infliximab: performance evaluation of three commercial ELISA kits. Clin Chem Lab Med. 2015;54:1211-1219.

16. Wolbink GJ, Vis $M$, Lems $W$, et al. Development of antiinfliximab antibodies and relationship to clinical response in patients with rheumatoid arthritis. Arthritis Rheum. 2006;54:711-715.

17. Marini JC, Sendecki J, Cornillie F, et al. Comparisons of serum infliximab and antibodies-to-infliximab tests used in inflammatory bowel disease clinical trials of Remicade ${ }^{\circledR}$. AAPS J. 2017;19:161-171.

18. Best WR, Becktel JM, Singleton JW, Kern F. Development of a Crohn's disease activity index. National cooperative crohn's disease study. Gastroenterology. 1976;70:439-444.

19. Truelove SC, Witts LJ. Cortisone in ulcerative colitis. $\mathrm{Br}$ Med J. 1955;2:1041-1048.

20. Casteele NV, Khanna R, Levesque BG, et al. The relationship between infliximab concentrations, antibodies to infliximab and disease activity in Crohn's disease. Gut. 2014;64:1539-1545.

21. Adedokun OJ, Sandborn WJ, Feagan BG, et al. Association between serum concentration of infliximab and efficacy in adult patients with ulcerative colitis. Gastroenterology. 2014;147:1296-1307.e5.

22. Reinisch W, Feagan BG, Rutgeerts PJ, et al. 566 Infliximab Concentration and Clinical Outcome in Patients With Ulcerative Colitis. Gastroenterology. 2012;142:S-114.

23. Vande Casteele N, Ferrante M, van Assche G, et al. Trough concentrations of infliximab guide dosing for patients with inflammatory bowel disease. Gastroenterology. 2015;148:1320-1329.e3.

24. Vande Casteele N, Gils A, Singh S, et al. Antibody response to infliximab and its impact on pharmacokinetics can be transient. Am J Gastroenterol. 2013;108:962-971.

25. Ungar B, Chowers $\mathrm{Y}$, Yavzori M, et al. The temporal evolution of antidrug antibodies in patients with inflammatory bowel disease treated with infliximab. Gut. 2014;63:1258-1264.

26. Papamichael K, Vande Casteele N, Gils A, et al. Long-term outcome of patients with Crohn's disease who discontinued infliximab therapy upon clinical remission. Clin Gastroenterol Hepatol. 2015;13:11031110.

27. Komaki Y, Yamada A, Komaki F, Micic D, Ido A, Sakuraba A. Systematic review with meta-analysis: the efficacy and safety of CT-P13, a biosimilar of anti-tumour necrosis factor- $\alpha$ agent (infliximab), in inflammatory bowel diseases. Aliment Pharmacol Ther. 2017;45: 1043-1057.

28. Warman A, Straathof JWA, Derijks LJJ. Therapeutic drug monitoring of infliximab in inflammatory bowel disease patients in a teaching hospital setting: results of a prospective cohort study. Eur J Gastroenterol Hepatol. 2015;27:242-248.

29. Jørgensen KK, Olsen IC, Goll GL, et al. Switching from originator infliximab to biosimilar CT-P13 compared with maintained treatment with originator infliximab (NOR-SWITCH): a 52-week, randomised, double-blind, non-inferiority trial. The Lancet. 2017;389: 2304-2316.

30. Kolar M, Duricova D, Bortlik M, et al. Infliximab biosimilar (Remsima $^{\mathrm{TM}}$ ) in therapy of inflammatory bowel diseases patients: experience from one tertiary inflammatory bowel diseases centre. Dig Dis Basel Switz. 2017;35:91-100.

31. Fiorino G, Manetti N, Armuzzi A, et al. The PROSIT-BIO Cohort: a prospective observational study of patients with inflammatory bowel disease treated with infliximab biosimilar. Inflamm Bowel Dis. 2017;23:233-243.

32. Argüelles-Arias F, Guerra Veloz MF, Perea Amarillo R, et al. Effectiveness and safety of CT-P13 (Biosimilar Infliximab) in patients with inflammatory bowel disease in real life at 6 months. Dig Dis Sci. 2017;62:2203. 
33. Ben-Horin S, Yavzori M, Benhar I, et al. Cross-immunogenicity: antibodies to infliximab in Remicade-treated patients with IBD similarly recognise the biosimilar Remsima. Gut. 2015;65:1132-1138.

34. Ruiz-Argüello MB, Maguregui A, Ruiz Del Agua A, et al. Antibodies to infliximab in Remicade-treated rheumatic patients show identical reactivity towards biosimilars. Ann Rheum Dis. 2016;75: 1693-1696.

35. Smits LJT, Derikx LAAP, de Jong DJ, et al. Clinical outcomes following a switch from Remicade ${ }^{\circledR}$ to the biosimilar CT-P13 in inflammatory bowel disease patients: a prospective observational cohort study. J Crohns Colitis. 2016;10:1287-1293.

36. Casanova MJ, Chaparro M, García-Sánchez V, et al. Evolution after anti-TNF discontinuation in patients with inflammatory bowel disease: a multicenter long-term follow-up study. Am J Gastroenterol. 2017;112:120-131.

37. Ben-Horin S, Chowers Y, Ungar B, et al. Undetectable anti-TNF drug levels in patients with long-term remission predict successful drug withdrawal. Aliment Pharmacol Ther. 2015;42:356-364.

38. Buer LCT, Moum BA, Cvancarova M, Warren DJ, Medhus AW, Høivik ML. Switching from Remicade ${ }^{\circledR}$ to Remsima ${ }^{\circledR}$ is well tolerated and feasible: a prospective open-label study. J Crohns Colitis. 2017;11:297-304.
39. Razanskaite $\mathrm{V}$, Bettey $\mathrm{M}$, Downey $\mathrm{L}$, et al. Biosimilar infliximab in inflammatory bowel disease: outcomes of a managed switching programme. J Crohns Colitis. 2017;11:690-696.

40. Tweehuysen L, van den Bemt BJF, van Ingen IL, et al. Subjective complaints as main reason for biosimilar discontinuation after open label transitioning from originator to biosimilar infliximab. Arthritis Rheumatol (Hoboken, N.J.). 2017; doi: 10.1002/art.40324

How to cite this article: Schmitz EMH, Boekema PJ, Straathof JWA, et al. Switching from infliximab innovator to biosimilar in patients with inflammatory bowel disease: a 12month multicentre observational prospective cohort study. Aliment Pharmacol Ther. 2017;00:1-8. https://doi.org/ 10.1111/apt.14453 